\title{
Differential diagnosis of a probable case of non-adult thalassaemia from 4th century AD Romano-British Colchester, UK
}

Article

Accepted Version

Creative Commons: Attribution-Noncommercial-No Derivative Works 4.0

Rohnbogner, A. (2016) Differential diagnosis of a probable case of non-adult thalassaemia from 4th century AD RomanoBritish Colchester, UK. International Journal of

Paleopathology, 15. pp. 39-49. ISSN 1879-9817 doi: https://doi.org/10.1016/j.ijpp.2016.08.002 Available at https://centaur.reading.ac.uk/67759/

It is advisable to refer to the publisher's version if you intend to cite from the work. See Guidance on citing.

To link to this article DOI: http://dx.doi.org/10.1016/j.ijpp.2016.08.002

Publisher: Elsevier

All outputs in CentAUR are protected by Intellectual Property Rights law, including copyright law. Copyright and IPR is retained by the creators or other copyright holders. Terms and conditions for use of this material are defined in the End User Agreement. 


\section{CentAUR}

Central Archive at the University of Reading

Reading's research outputs online 
Accepted by the International Journal of Palaeopathology on 02/08/2016

\title{
Title
}

Differential diagnosis of a probable case of non-adult thalassaemia from $4^{\text {th }}$ century AD Romano-British Colchester, UK

\section{Author name and affiliation (corresponding author)}

Anna Rohnbogner, University of Reading, UK

Department of Archaeology, School of Archaeology, Geography and Environmental Science, University of Reading, Reading, England, UK, RG6 6AB

a.j.rohnbogner@reading.ac.uk

\begin{abstract}
Our current understanding of immigration and diasporic disease in Roman Britain has been greatly enhanced by the recent identification of thalassaemia in the non-adult skeletal record. The wide phenotypic variation in the clinical expression of $\beta$-thalassaemia, however, means that additional cases may go unrecognised. A probable diagnosis for $\beta$-thalassaemia intermedia or a mild form of major in a 1.0-1.5 year old skeleton from Butt Road, Colchester, dating to the $4^{\text {th }}$ century $\mathrm{AD}$ is discussed here. The assessment was undertaken using macroscopic and radiographic analysis. Several conditions were apparent, including trauma and probable $\beta$-thalassaemia and active vitamin D deficiency. Diagnosis proved difficult due to the challenges that non-adult thalassaemia poses for identification in the skeletal record, as in the absence of the cranium only 'rib-within-a-rib' is currently considered as pathognomonic of the condition. This case demonstrates the variations in expression of this type of genetic anaemia and adds emphasis to a more widespread presence of this important condition in Roman Britain.
\end{abstract}

\section{Keywords}

Anaemia - migration - rickets - vitamin D deficiency - fracture 


\section{Introduction}

Thalassaemia has been identified in the Romano-British non-adult skeletal record, however diagnoses remain challenging due to the varied expression of the disease and the low number of published cases (Taher et al. 2006; Lewis 2012). Diagnoses have been hindered by the lack of pathognomonic features and the non-specific nature of cribra orbitalia and porotic hyperostosis (Ortner 2003, 364-365). To date, the only cases of probable non-adult $\beta$ thalassaemia in Roman Britain have been recovered from $3^{\text {rd }}-5^{\text {th }}$ century AD Poundbury Camp, Dorchester, Dorset (Lewis 2012) (Fig. 1). Since the disease is not endemic to Britain, but the Mediterranean, these cases provide direct osteological evidence for immigration to Roman England.

The alterations of the haemoglobin molecules and red blood cells in $\beta$-thalassaemia give the carrier an increased immunity to malaria (Plasmodium vivax and Plasmodium falciparum) (Hershkovitz et al. 1991, 1997; O’Donnell et al. 2009). This type of genetic anaemia is therefore a result of genetic polymorphisms perpetuated by a resistance to malaria. Heterozygous individuals display partial immunity, whereas homozygous carriers are fully immune but suffer from $\beta$-thalassaemia intermedia or major (Mitchell 2003; Ustundag 2011), with $\beta$-globin protein production partially suppressed due to defective gene function (Taher et al. 2006) (Table 1). Costal osteomas and 'rib-within-a-rib' lesions have been noted as suggestive of $\beta$-thalassaemia intermedia (Lawson et al. 1981; Tunaci et al. 1999).

Subsequently, Lewis (2012) demonstrated that changes in the thorax, and lesions attributed to anaemia are likely to be skeletal manifestations of non-adult $\beta$-thalassaemia. This case study aims to highlight the challenges of a differential diagnosis in incomplete non-adult remains and showcases the range of expressions observable in probable cases of non-adult $\beta$ thalassaemia.

\section{Materials and Methods}

The colonia of Vitricensis Camulodunensium was founded on the oppidum of Camulodunum and is now contained within modern day Colchester, Essex (Wacher 1974, 104; Brooks 2006; Black 2006) (Fig. 1). The burial ground at Butt Road was excavated from 1976-1979, and during 1986-1988 by Colchester Archaeological Trust (Crummy and Crossan 1993, 4). The cemetery is situated outside of the walled town by the main south-west gate. The phases of 
the cemetery dating to the $4^{\text {th }}-5^{\text {th }}$ centuries hold the remains of 109 non-adults aged $0-17$ years old (15.6\%), with a total of 700 recovered individuals (Crummy and Crossan 1993, 62; Pinter-Bellows 1993).

G145 was recovered as a single unfurnished inhumation from the eastern edge of the cemetery (Crummy and Crossan 1993) (Fig. 2). The non-adult was aged to a mean dental age of 1.0-1.5 years, based on crown formation of the permanent first mandibular molar and root formation stages of the deciduous first and second mandibular molars (Moorrees et al. 1963a,b). G145 is represented by elements of the trunk, upper limbs and long bone fragments. The skull is absent apart from maxillary and sphenoid fragments (Fig. 3). The individual displayed noteworthy rib lesions and pathological changes to the upper limbs.

A range of conditions have to be considered for the nature of the lesions observed, including $\beta$-thalassaemia (Table 1). Diagnoses are based on macroscopic assessment and digital radiography undertaken at the University of Reading.

\section{Results}

Upper limbs show microporosity of the cortical bone, with enlarged trabecular structure and cortical thinning suggestive of osteopenia, the latter also apparent in the ilium (Figs. 4, 5). Thickening towards epiphyseal ends is evident in the long bones (Figs. 6, 7). The right radius appears thickened and angled at the distal third of the diaphysis with a transverse band of remodelled woven bone, indicative of a fracture callus (Figs. 7). Radiographically, the affected area presents as a fracture of the metaphysis which resulted in angulation of the distal portion and widespread new bone deposits (Fig. 8). Radiographs reveal a radiolucent band at the distal metaphysis of the left radius (Fig. 8).

Bilaterally, ribs appear flared and thickened at the costo-chondral end with increased porosity (Figs. 9-11). Several ribs display localised thickening of the shafts, reminiscent of 'swelling' with one expanded focus per element (Fig. 10, 11). These areas of hyper-marrow bone occur bilaterally, although primarily on the right (five right ribs, one left rib). Macroscopically, the expanded foci do not appear porous, or as healed sub-periosteal new bone formation, but rather as localised masses of dense compact bone sitting on top of the original cortical bone (Fig. 11). Radiographs indicate osteopenia, and reveal a radio-opaque appearance of the foci of lamellar bone deposited on the original cortex (Figs. 12, 13). 


\section{Discussion}

Due to the incomplete preservation of the remains and the ambiguous nature of the lesions, several probable causes have to be considered (Table 1). Changes to rib ends, cortical microporosity throughout and a radiolucent band at the left radius strongly suggest active vitamin D deficiency at the time of death (Ortner and Mays 1998; Ortner 2003). It may be suggested that given the fact that this child was sickly, it may have been kept indoors for a prolonged period which exacerbated its vitamin D deficient status. Recent considerations of the disease have demonstrated that skeletal changes attributed to rickets/osteomalacia represent the most extreme end of the disease spectrum, often associated with a range of comorbidities (Snoddy et al. 2016).

Since G145 suffered from active rickets at the time of death, the child may have also been affected by respiratory disease (Pettifor and Daniels 1997; Pettifor 2003). A non-specific respiratory infection may cause visceral new bone formation which has to be discussed as a possible aetiology of the observed rib lesions, alongside rib fractures as a result of violent coughing (Lovell 1997). Proliferation in respiratory infections is most commonly apparent towards the vertebral end and often occurs bilaterally (Santos and Roberts 2001), the location of foci on the ribs of G145 is however inconsistent and isolated. In expansive visceral lesions, porous new bone blends into the existing shape of the rib shaft which is difficult to differentiate macroscopically. However, radiographs confirm a layer of compact bone on the original cortex rather than a blending of original and newly formed bone (Matos and Santos 2006; Lagia et al. 2007). Fracture lines are absent on radiographs of all ribs, and new cortical bone is deposited at the mid-shaft, primarily anteriorly and on top of the original cortex, appearing as localised masses rather than fracture callouses (Lewis 2012).

Although G145 does not display the extreme skeletal alterations described by Lagia et al. (2007) and Lewis (2012) for $\beta$-thalassaemia intermedia, there is wide phenotypic variation in clinical expression which may account for the less extreme skeletal changes observed (Weatherall and Clegg 1999). Although the pathognomonic 'rib-within-a-rib' is absent, the cortical swelling in the ribs conforms with a diagnosis for costal osteomas. The cortical porosity and swelling observed throughout the skeleton are apparent in $\beta$-thalassaemia intermedia and mild forms of major. Additionally, osteopenia has been observed in cases of non-adult $\beta$-thalassaemia (Lewis 2012). Yet, in the absence of cranial and facial bones, the characteristic 'rodent face' (Almeida and Roberts 2005; Tyler et al. 2006) and 'hair-on-end' 
(Hershkovitz et al. 1997) as thalassaemic traits cannot be assessed for, urging for a consideration of sickle-cell anaemia in G145. The most common complication in sickle-cell disease is vaso-occlusive crisis. Blood vessels are congested by sickle-cell red blood cells, hindering circulation and leading to arthritic changes, dactylitis, or vertebral collapse (Almeida and Roberts 2005). Bone marrow infarction has not been observed which makes sickle-cell anaemia unlikely, although the incomplete skeleton of G145 does not allow for this type of genetic anaemia to be fully ruled out.

The trauma on the right distal radius possibly describes a torus fracture with buckling of the cortex, or a greenstick fracture with the cortex intact on the ulnar aspect, albeit only minimal (Ogden 2000, 617). Looser's zone has to be considered as a pathological pseudo-fracture in the distal radius due to rickets (Aufderheide and Rodriguez-Martin 1998, 307; Keller and Barnes 2008). However, the fracture presents with angulation and displacement which refutes a pseudo-fracture (Keller and Barnes 2008). The radial fracture may be the result of loss in bone mineral density secondary to genetic anaemia, and probably exacerbated by active rickets (Michelson and Cohen 1988; Keller and Barnes 2008). Generally, children around 18 months old start walking, and given the angle of the fracture a fall may be a likely cause. However, we have to consider that G145 was limited in mobility and the fracture arose due to general weightbearing in crawling or handling.

\section{Conclusion}

The lesions apparent in this non-adult skeleton provide several diagnostic challenges. The missing cranium prevents from making a conclusive diagnosis of $\beta$-thalassaemia major or intermedia, although co-occurrence of thalassaemia and active rickets is likely. This case may be used to illustrate the difficulty in diagnosing the $\beta$-thalassaemias in non-adults, and the possibility for less severe lesions which may be easily overlooked during osteological analysis and recording. This case demonstrates the need to look for $\beta$-thalassaemia in the Romano-British non-adult skeletal record, and the importance of awareness of the varied expressions this particular anaemia may yield. Evidently, this case also demonstrates that the disease was not unique to Poundbury Camp, and provides direct skeletal evidence for migrants in Roman Colchester. 


\section{Acknowledgements}

I thank Dr Mary Lewis for comments on an earlier draft. I am indebted to Dr Paul Sealey and Jessica Dodwell at Colchester and Ipswich Museums for access to the Butt Road skeletal archive, Colchester Archaeological Trust for use of the figures, and Luke Robinson for his expertise. I am grateful to the anonymous reviewers for their detailed and constructive comments to improve an earlier version of this paper. This research was funded by an AHRC PhD studentship.

\section{Literature cited}

Almeida A and Roberts I, 2005. Bone involvement in sickle cell disease. British Journal of Haematology 129, 482-490

Aufderheide A C and Rodriguez-Martin C, 1998. The Cambridge Encyclopedia of Human Paleopathology. Cambridge, Cambridge University Press

Barsness K A, Cha E, Bensard D, Calkins C M, Partrick D A, Karrer F M and Strain J D, 2003. The positive predictive value of rib fractures as an indicator of nonaccidental trauma in children. The Journal of Trauma Injury, Infection, and Critical Care 54(6), 1107-1110

Black E W, 2006. The pre-Boudican Colonia at Camulodunum. In: Ottaway P (ed). A Victory Celebration: Papers on the Archaeology of Colchester and Late Iron-Age Roman Britain presented to Philip Crummy. Colchester, Colchester Archaeological Trust, 43-54

Brooks H, 2006. Colchester before Colchester. In: Ottaway P (ed). A Victory Celebration: Papers on the Archaeology of Colchester and Late Iron-Age Roman Britain presented to Philip Crummy. Colchester, Colchester Archaeological Trust, 5-10

Crummy N and Crossan C, 1993. Excavations at Butt Road Cemetery, 1976-9, 1986 and 1989. In; Crummy N, Crummy P and Crossan C. Colchester Archaeological Report 9: Excavations of Roman and Later Cemeteries, Churches and Monastic Sites in Colchester, 1971-88. Colchester, Colchester Archaeological Trust, 4-163

Crummy N, Crummy P and Crossan C. Colchester Archaeological Report 9: Excavations of Roman and Later Cemeteries, Churches and Monastic Sites in Colchester, 1971-88.

Colchester, Colchester Archaeological Trust 
Galanello R and Cao A, 1998. Relationship between genotype and phenotype: Thalassemia Intermedia. Annals of the New York Academy of Sciences 850(1), 325-333

Hershkovitz I, Ring B, Speirs M, Galili E, Rislev M, Edelson G and Hershkovitz A, 1991. Possible congenital hemolytic anemia in prehistoric coastal inhabitants of Israel. American Journal of Physical Anthropology 85(1), 7-13

Hershkovitz I, Rothschild B M, Latimer B, Dutour O, Leonetti G, Greenwald C M, Rothschild C and Jellana L M, 1997. Recognition of sickle cell anemia in skeletal remains of children. American Journal of Physical Anthropology 104, 213-226

Keller K A and Barnes P D, 2008. Rickets vs. abuse: a national and international epidemic. Pediatric Radiology 38(11), 1210-1216

Lagia A, Eliopoulus C and Manolis S, 2007. Thalassaemia: macroscopic and radiological study of a case. International Journal of Osteoarchaeology 17, 269-285

Lawson J P, Ablow R C and Pearson H A, 1981. The ribs in thalassaemia II. The pathogenesis of the changes. Radiology 140(3), 673-679

Lewis M E, 2010. Life and death in a civitas capital: metabolic disease and trauma in the children from late Roman Dorchester, Dorset. American Journal of Physical Anthropology $142,405-416$

Lewis M E, 2011. Tuberculosis in the non-adults from Romano-British Poundbury Camp, Dorset, England. International Journal of Palaeopathology 1, 12-23

Lewis M E, 2012. Tuberculosis in the non-adults from Romano-British Poundbury Camp, Dorset, England. International Journal of Palaeopathology 1, 12-23

Lovell N C, 1997. Trauma analysis in paleopathology. Yearbook of Physical Anthropology $40,139-170$

Matos V and Santos V L, 2006. On the trail of pulmonary tuberculosis based on rib lesions: results from the Human Identified Skeletal Collection from the Museu Bocage (Lisbon, Portugal). American Journal of Physical Anthropology 130, 190-200

Mays S, Brickley M and Ives R, 2006. Skeletal manifestations of rickets in infants and young children in a historic population from England. American Journal of Physical Anthropology $129,362-374$ 
Michelson J and Cohen A, 1988. Incidence and treatment of fractures in thalassemia. Journal of Orthopedic Trauma 2(1), 29-32

Mitchell P, 2003. The archaeological study of epidemic and infectious disease. World Archaeology 35(2), 171-199

Moorrees CFA, Fanning E A and Hunt E E, 1963a. Age variation of formation stages for ten permanent teeth. Journal of Dental Research 42, 1490-1502

Moorrees CFA, Fanning E A and Hunt E E, 1963b. Formation and resorption of three deciduous teeth in children. American Journal of Physical Anthropology 21, 205-213

O’Donnell A, Premawardhena A, Arambepola M, Samaranayake R, Allen S J, Peto T E A, Fisher C A, Cook J, Corran P H, Olivieri N F and Weatherall D J, 2009. Interaction of malaria with a common form of severe thalassemia in an Asian population. PNAS 106(44), 18716-18721

Ogden J A, 2000. Skeletal Injury in the Child (3rd edition). New York, Springer Ortner D J, 2003. Identification of Pathological Conditions in Human Skeletal Remains (2nd edition). San Diego, Academic Press

Ortner D J and Mays S, 1998. Dry-bone manifestations of rickets in infancy and early childhood. International Journal of Osteoarchaeology 8, 45-55

Pettifor J M, 2003. Nutritional rickets. In: Glorieux F H, Pettifor J M and Jüppner H (eds). Pediatric Bone - Biology and Diseases. San Diego, Academic Press, 541-565

Pettifor J and Daniels E, 1997. Vitamin D deficiency and nutritional rickets in children. In: Feldman D, Glorieux F and Pike J (eds). Vitamin D. New York, Academic Press, 663-678 Pfeiffer S, 1991. Rib lesions and New World tuberculosis. International Journal of Osteoarchaeology 1, 191-198

Pinter-Bellows S, 1993. The human skeletons. In: Crummy N, Crummy P and Crossan C. Colchester Archaeological Report 9: Excavations of Roman and Later Cemeteries, Churches and Monastic Sites in Colchester, 1971-88. Colchester, Colchester Archaeological Trust, 6291

Roberts C A, Boylston A, Buckley L, Chamberlain A C and Murphy E M, 1998. Rib lesions and tuberculosis: the palaeopathological evidence. Tubercle and Lung Disease 79, 55-60 
Roksandic M, 2003. New standardised visual forms for recording the presence of human skeletal elements in archaeological and forensic contexts. Internet Archaeology 01/2003

Rund D and Rachmilewitz E, 2005. $\beta$-Thalassemia. New England Journal of Medicine 353(11), 1135-1146

Santos A L and Roberts C A, 2001. A picture of tuberculosis in young Portuguese people in the early 20th century: a multidisciplinary study of the skeletal and historical evidence. American Journal of Physical Anthropology 115, 38-49

Snoddy A M E, Buckley H R and Halcrow S E, 2016. More than metabolic: considering the broader paleoepidemiological impact of vitamin D deficiency in bioarchaeology. American Journal of Physical Anthropology 160, 183-196

Taher A, Isma'eel H and Cappellini M D, 2006. Thalassemia intermedia: revisited. Blood Cells, Molecules, and Diseases 37(1): 12-20

Thein S, 2005. Genetic modifiers of beta-thalassemia. Haematologica 90(5), 649-660 Tunaci M, Tunaci A, Engin G, Özkorkmaz B, Dincol G, Acunas G and Acunas B, 1999. Imaging features of thalassaemia. European Radiology 9(9), 1804-1809

Tyler P A, Madani G, Chaudhuri R, Wilson L F and Dick E A, 2006. The radiological appearances of thalassaemia. Clinical Radiology 61, 40-42

Ustundag H, 2011. Anemia in the light of genetic, environmental and cultural factors: cases of some ancient Anatolian populations. Tuba-Ar-Turkish Academy of Sciences Journal of Archaeology 14, 173-192

Wacher J, 1974. The Towns of Roman Britain. London, Batsford

Weatherall D J and Clegg J B, 1999. Genetic disorders of haemoglobin. Seminars in Hematology 36, 24-37 
Table 1. Genetic and clinical status of the $\beta$-thalassaemias

\begin{tabular}{|c|c|c|c|}
\hline Feature & $\beta$-thalassaemia minor & $\beta$-thalassaemia intermedia & $\beta$-thalassaemia major \\
\hline $\begin{array}{l}\text { Genetic } \\
\text { pathology }\end{array}$ & $\begin{array}{l}\text { Heterozygous: one } \beta \text {-globin } \\
\text { gene with mutation }(2,3)\end{array}$ & $\begin{array}{l}\text { Mostly homozygous or rarely compound } \\
\text { heterozygous: two } \beta \text {-globin genes with } \\
\text { mutation, one of which is mild; or one } \beta \text { - } \\
\text { globin mutation combined with } \alpha \text {-globin } \\
\text { genes }(1,2)\end{array}$ & $\begin{array}{l}\text { Homozygous: two } \beta \text {-globin genes } \\
\text { with severe mutation }(2,3,5)\end{array}$ \\
\hline $\begin{array}{l}\text { Clinical } \\
\text { status }\end{array}$ & $\begin{array}{l}\text { Anaemia mild or absent, } \\
\text { very limited to no skeletal } \\
\text { changes }(2,5)\end{array}$ & $\begin{array}{l}\text { Anaemia, transfusion-independent, skeletal } \\
\text { involvement }(2,5)\end{array}$ & $\begin{array}{l}\text { Iron overload, severe anaemia, } \\
\text { transfusion-dependent, skeletal } \\
\text { involvement }(2,3,5)\end{array}$ \\
\hline $\begin{array}{l}\text { Phenotypic } \\
\text { expression }\end{array}$ & Asymptomatic/silent $(2,3,5)$ & $\begin{array}{l}\text { On a spectrum from asymptomatic to } \\
\text { severe, discernible in osteological record as } \\
\text { gross skeletal changes but able to live into } \\
\text { later life }(2,3,4,5)\end{array}$ & $\begin{array}{l}\text { Severe, lifelong reliance on blood } \\
\text { transfusions and supportive care, } \\
\text { probably not have survived past the } \\
\text { age of two years in the past }(2,5)\end{array}$ \\
\hline
\end{tabular}

From 1, Galanello and Cao (1998); 2, Rund and Rachmilewitz (2005); 3, Thein (2005); 4,

Taher et al. (2006); 5, Lagia et al. (2007) 
Table 2. Features of non-adult pathological conditions that may cause rib lesions including the $\beta$-thalassaemias

\begin{tabular}{|c|c|c|c|c|c|}
\hline Element & Non-specific respiratory infections & Trauma & & Vitamin D deficiency & $\beta$-thalassaemia intermedia and major \\
\hline Ribs & $\begin{array}{ll}- & \text { visceral rib lesions }(7,14) \\
- & \text { lesions as layers of dense } \\
& \text { periosteal new bone, } \\
& \text { resorption or plaque } \\
& \text { formation (1) } \\
- & \text { expansion: new bone blends } \\
& \text { into existing bone shape (14) } \\
- & \text { - proliferation most apparent } \\
\text { towards vertebral end and } \\
\text { often occurs bilaterally (9) }\end{array}$ & - & $\begin{array}{l}\text { complete or partial rib fractures } \\
\text { rachitic children are susceptible } \\
\text { to respiratory disease such as } \\
\text { whooping cough leading to rib } \\
\text { fractures due to weakened bone } \\
(4,12) \\
\text { stress fractures due to continuous } \\
\text { coughing and/or vomiting (3) } \\
\text { often result from blunt chest } \\
\text { trauma and deliberate injury (8) }\end{array}$ & $\begin{array}{l}\text { flaring, thickening and increased porosity } \\
\text { at costo-chondral end (6) } \\
\text { fractures may arise as a result of } \\
\text { weakened bone through continuous }) \\
\text { coughing, vomiting or overly tight } \\
\text { swaddling }(3,4,12,19)\end{array}$ & $\begin{array}{l}\text { Costal osteoma } \\
\text { - } \quad \text { benign neoplastic lesion mostly formed of lamellar } \\
\text { swollen aspects of hyper-marrow bone on the } \\
\text { - } \quad \text { riginal cortex of the rib }(17,21) \\
\text { - } \quad \text { cadio-opaque appearance }(21) \\
\text { interpreting these osteomas without the use of } \\
\text { radiographs, as they emerge similar to fracture } \\
\text { calluses (21) } \\
\text { Rib-within-a-rib } \\
\text { radiographs: radio-opaque band within the affected } \\
\text { rib (16) } \\
\text { longitudinal marrow expansion within the cortex } \\
\text { (16) } \\
\text { posterior aspects of the ribs expand posteriorly } \\
\text { which may correspond with paraspinal extra- } \\
\text { medullary haematopoiesis (16) } \\
\text { gross macroscopic examination: rib-within-a-rib } \\
\text { appearance emerges as pitting and thickening of the } \\
\text { ribs with hypertrophic aspects and costal osteomas } \\
\text { (21) }\end{array}$ \\
\hline Skull & $\begin{array}{l}\text { - } \quad \text { endocranial lesions may be } \\
\text { observed (20) }\end{array}$ & & $\begin{array}{l}\text { additional if arisen secondary to } \\
\text { underlying condition such as } \\
\text { vitamin D deficiency }\end{array}$ & $\begin{array}{ll}\text { - } & \text { craniotabes } \\
\text { - } & \text { porosity and pitting on ectocranial aspect } \\
& (6,15)\end{array}$ & $\begin{array}{ll}\text { - } & \text { porotic hyperostosis, 'hair-on end' }(2,11,16,17, \\
& 21) \\
\text { - } & \text { cribra orbitalia }(11,17) \\
\text { - } & \text { generalised periosteal and/or trabecular thickening } \\
& (11,16,17,21) \\
\text { - } & \text { 'rodent face' }(13,16)\end{array}$ \\
\hline
\end{tabular}




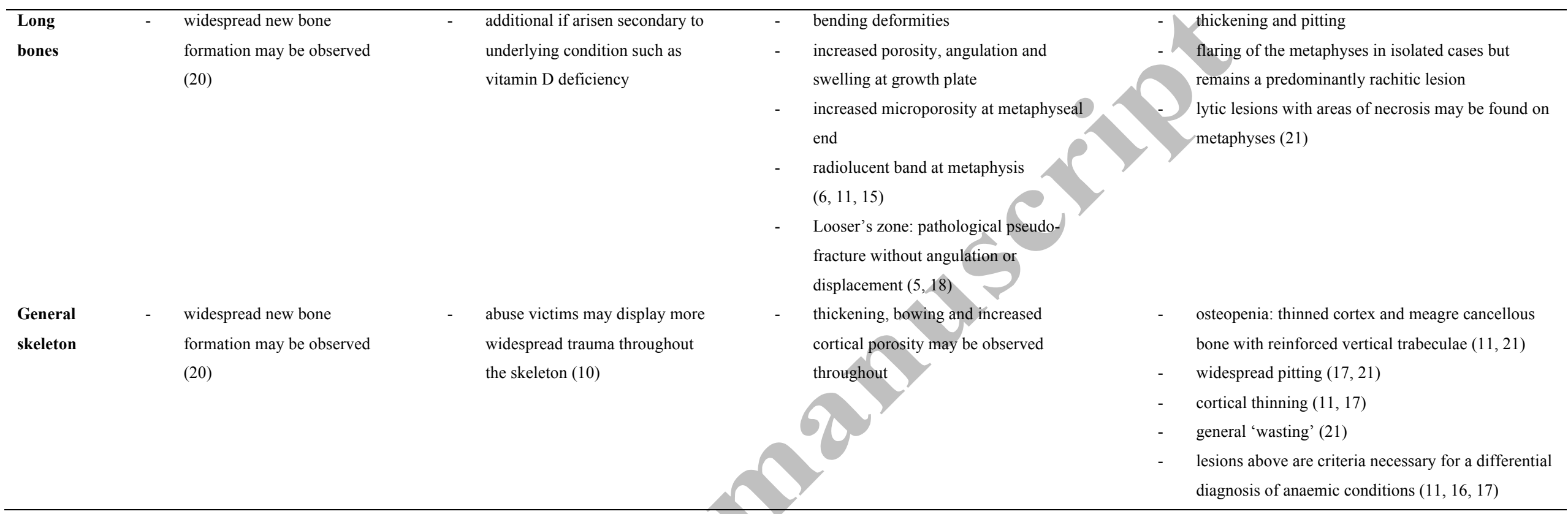

From 1, Pfeiffer (1991); 2, Hershkovitz et al. (1997); 3, Lovell (1997); 4, Pettifor and Daniels (1997); 5, Aufderheide and Rodriguez-Martin (1998, 307); 6, Ortner and Mays (1998); 7, Roberts et al. (1998); 8, Ogden (2000, 422-424); 9, Santos and Roberts (2001); 10, Barsness et al. (2003); 11, Ortner (2003); 12, Pettifor (2003); 13, Almeida and Roberts (2005); 14, Matos and Santos (2006); 15, Mays et al. (2006); 16, Tyler et al. (2006); 17, Lagia et al. (2007); 18, Keller and Barnes (2008); 19, Lewis (2010); 20, Lewis (2011); 21, Lewis (2012)

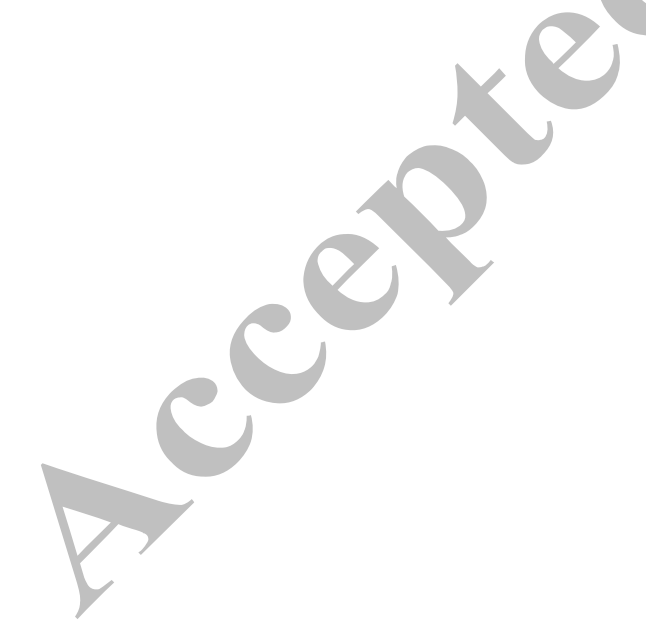




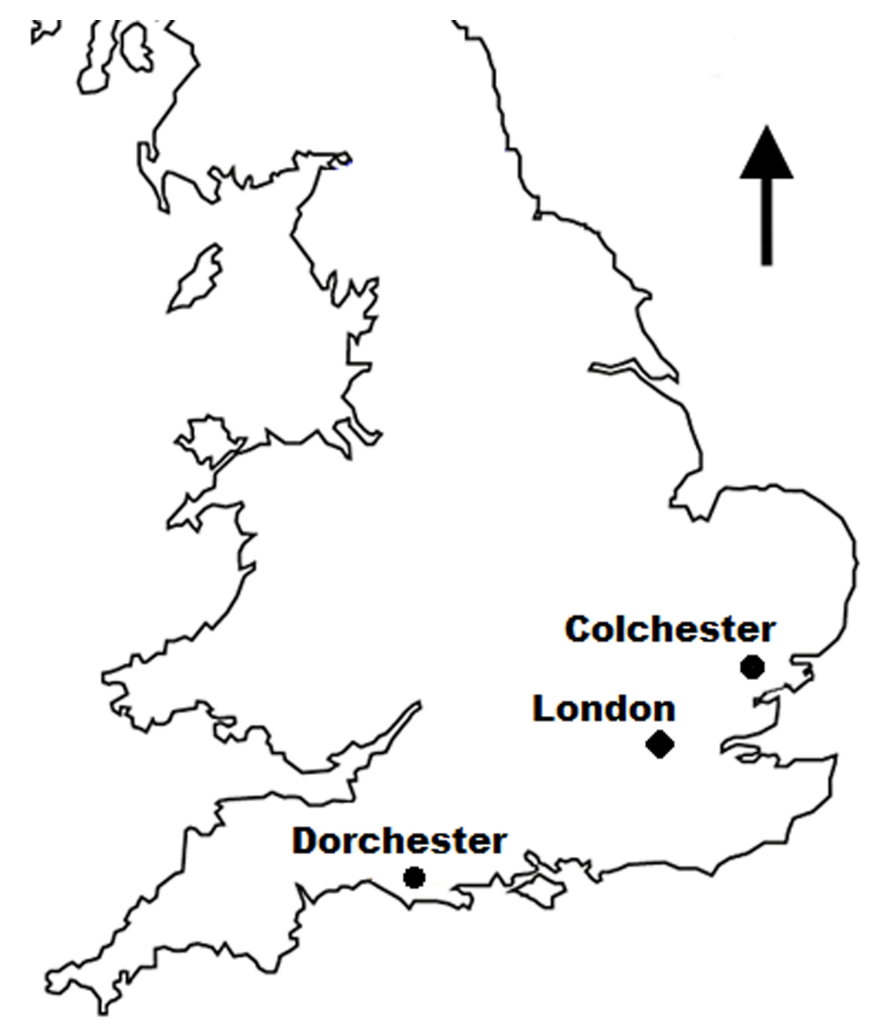

Figure 1. Location of the Dorchester and Colchester sites. 


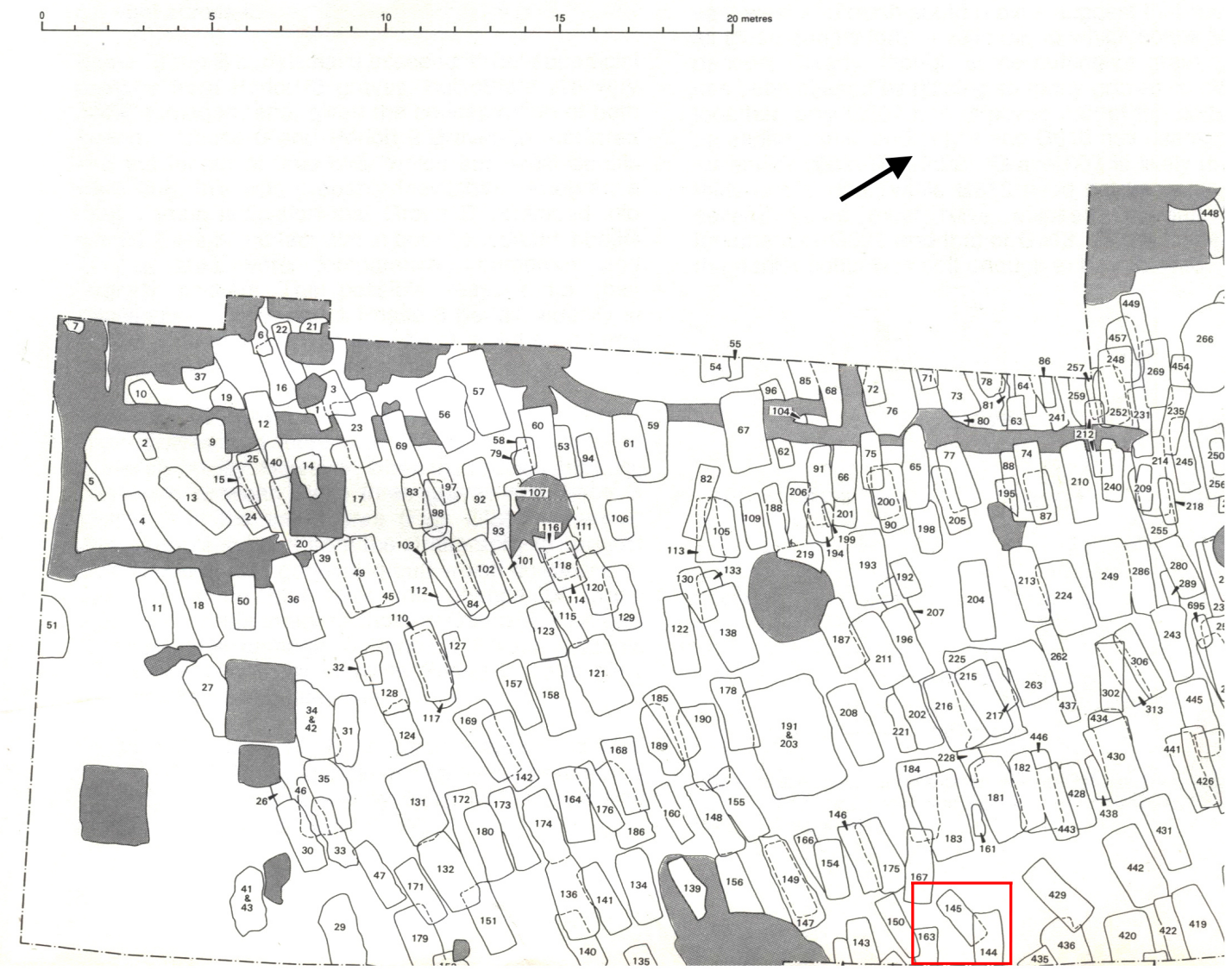

Figure 2. Southern portion of the $4^{\text {th }}$ century cemetery at Butt Road (from Crummy et al. 1993). Location of G145 highlighted in red. Reproduced with kind permission from Colchester Archaeological Trust. 


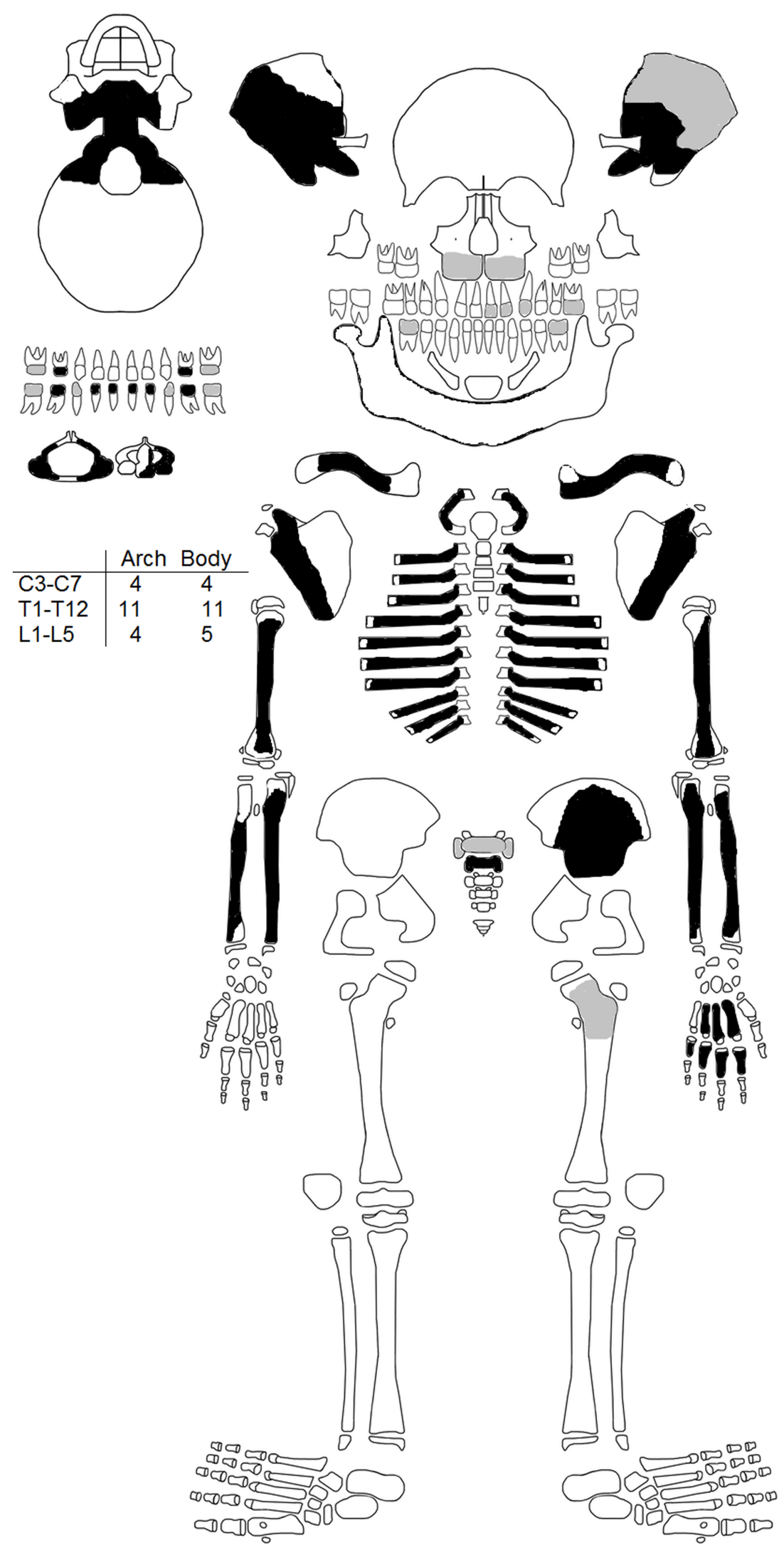

Figure 3. Skeletal inventory (black: present, white: missing, grey: fragmentary; dentition: grey denotes unerupted; template from Roksandic 2003). 


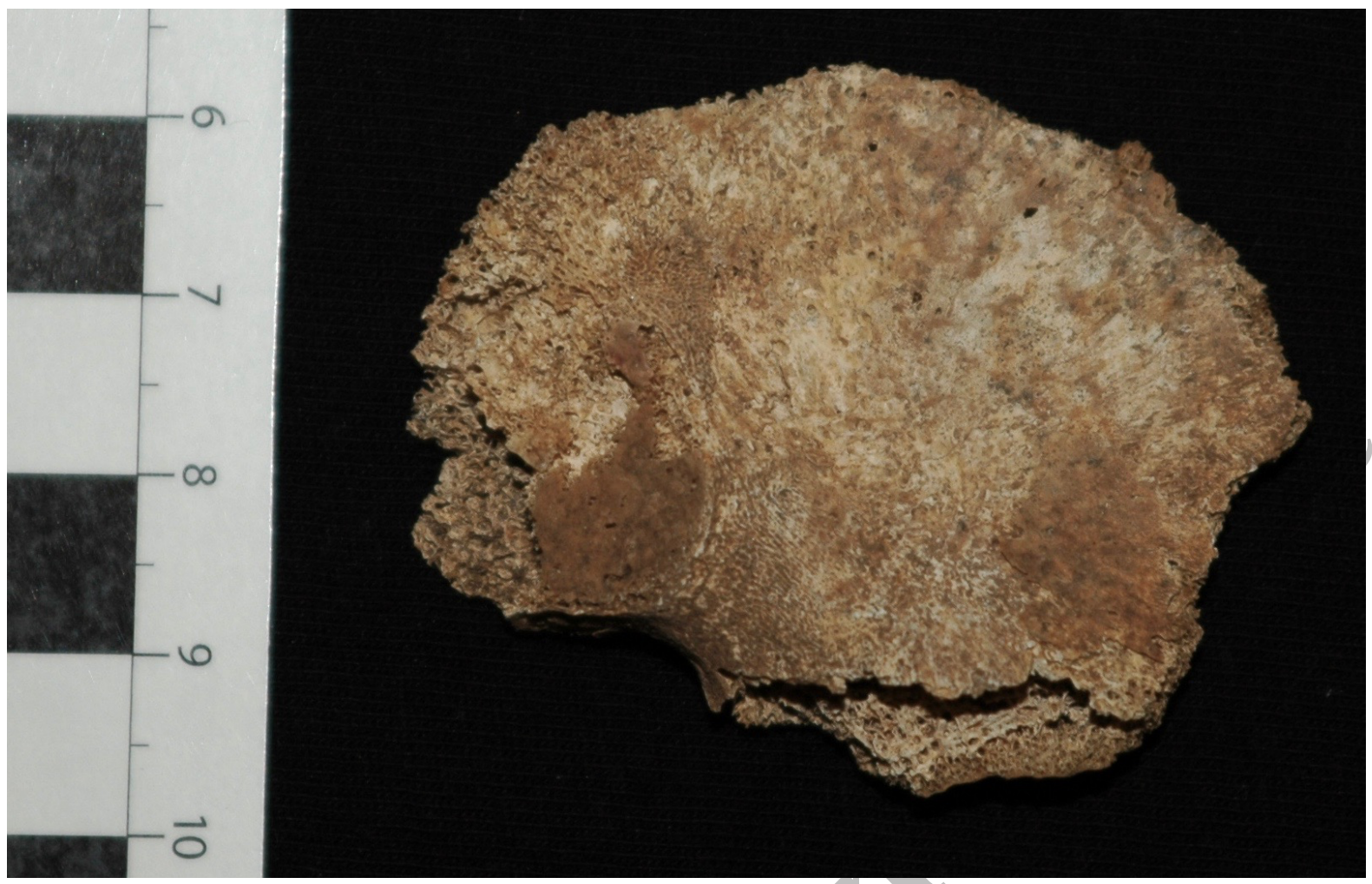

Figure 4. Left ilium, anterior. Coarsening and enlargement of trabecular structure apparent due to post-mortem damage around the acetabulum and sacro-iliac joint. From Butt Road, Colchester, skeleton 145 (with permission from Colchester and Ipswich Museums). 


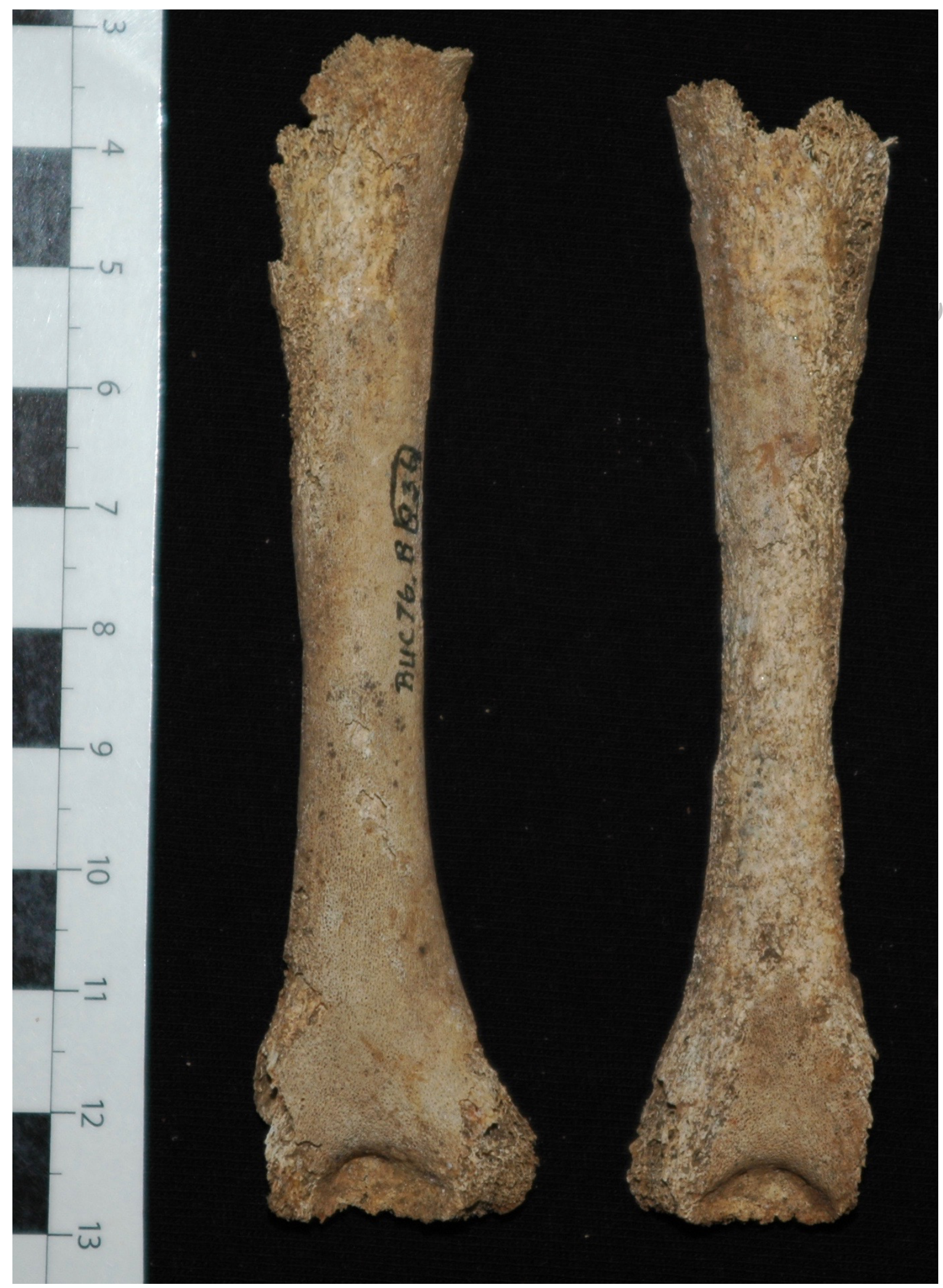

Figure 5. Humerii, posterior. Cortical pitting and porosity, with both elements appearing thickened and 'plump' towards the metaphyses. From Butt Road, Colchester, skeleton 145 (with permission from Colchester and Ipswich Museums). 

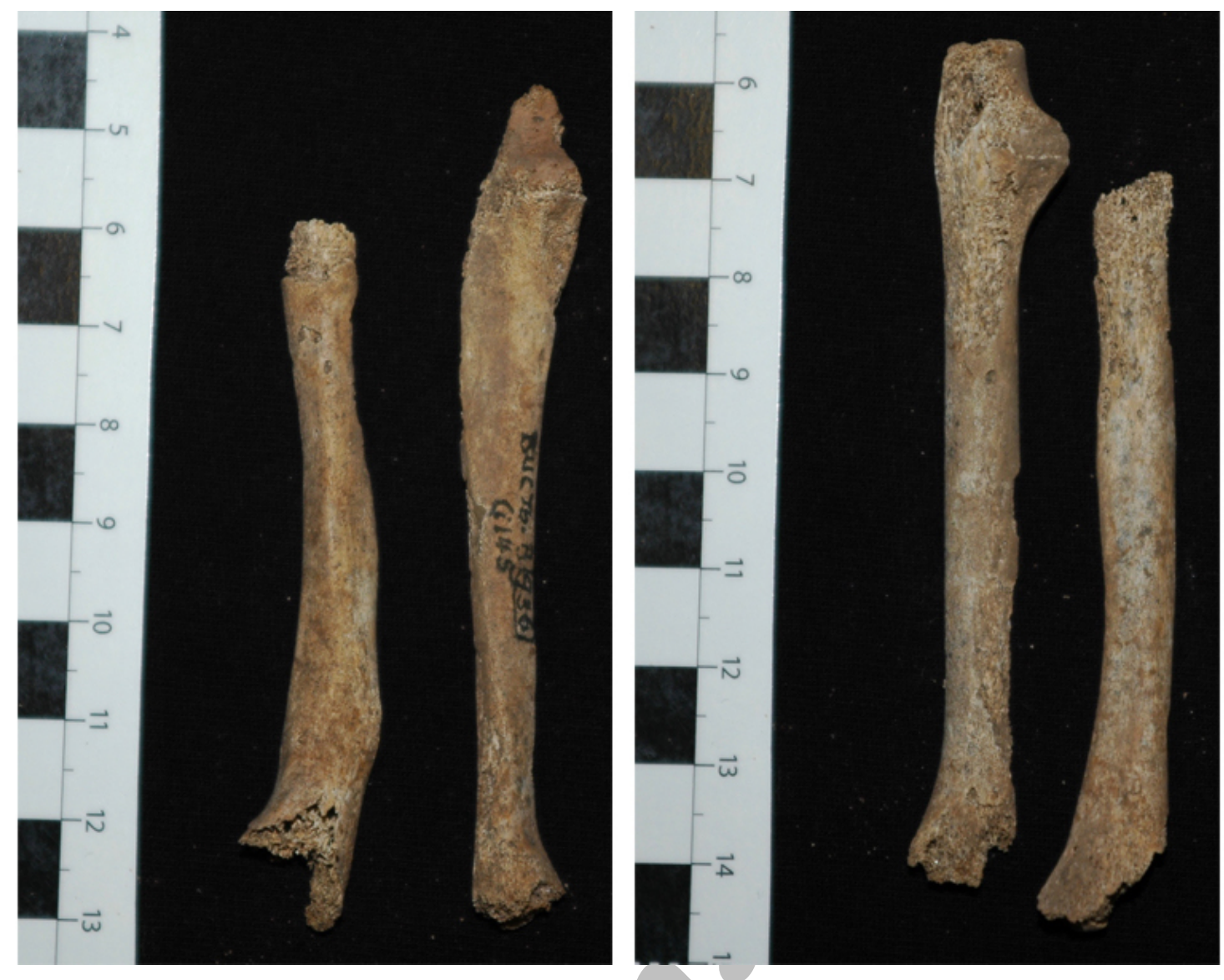

Figure 6. Radii and ulnae, anterior. Thickened and 'plump' with cortical thinning and enlarged epiphyseal ends. Right radius (far left) with fracture at distal third of diaphysis. From Butt Road, Colchester, skeleton 145 (with permission from Colchester and Ipswich Museums) 


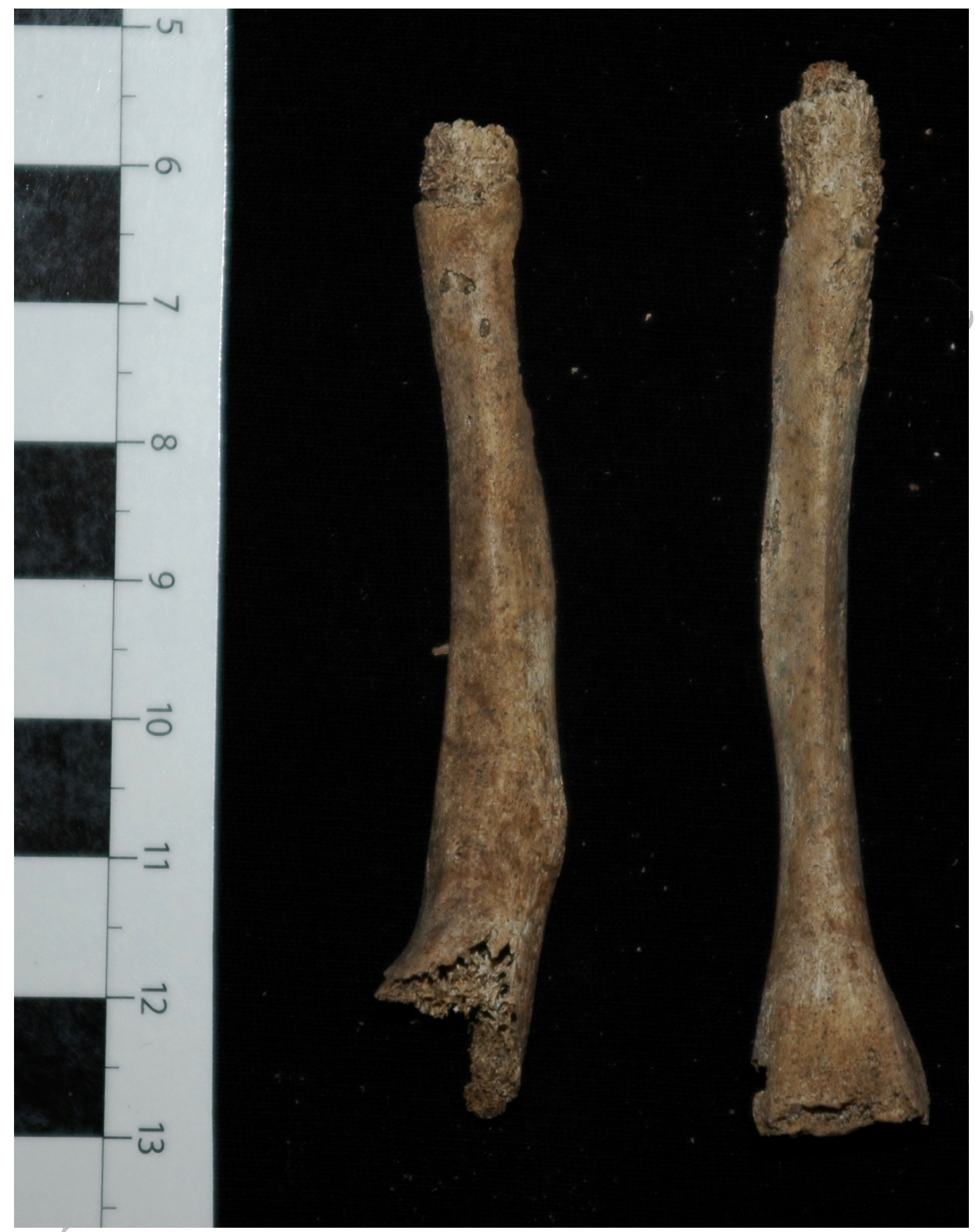

Figure 7. Radii, medial. Right radius (left) with angulation, expansion and thickening of distal third of shaft due to fracture; post-mortem damage reveals enlarged trabecular structure. Left radius (right) displays enlarged 'swollen' distal end with increased pitting and porosity of the metaphyseal plate. From Butt Road, Colchester, skeleton 145 (with permission from Colchester and Ipswich Museums). 


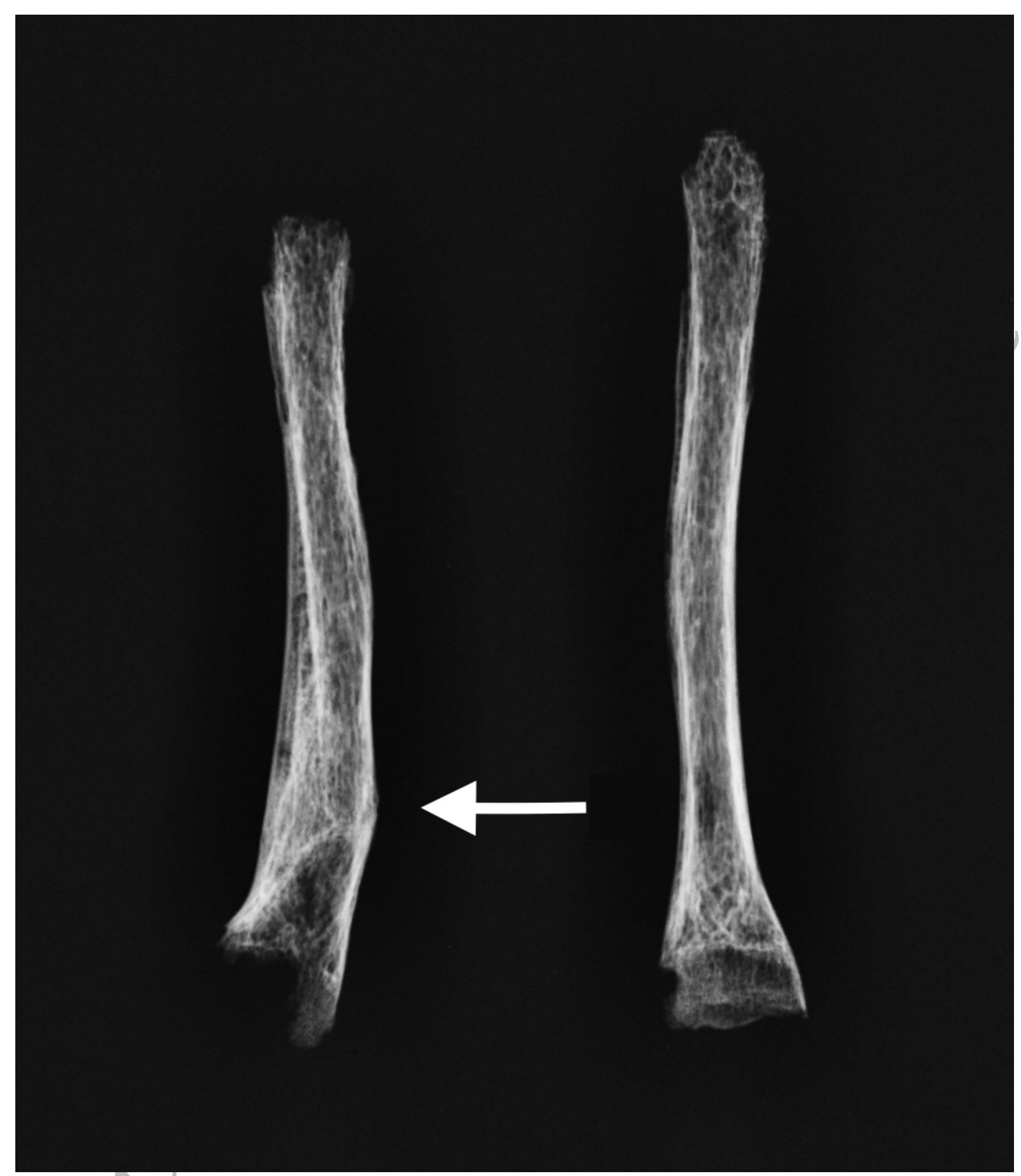

Figure 8. Digital radiograph of radii, medial. Fracture callus on the right distal radius (left, with arrow), note cortical thinning at epiphyseal ends and enlarged trabecular structure with re-inforced woven bone in both elements. Left distal radius with radiolucent band at distal metaphysis. From Butt Road, Colchester, skeleton 145 (with permission from Colchester and Ipswich Museums). 

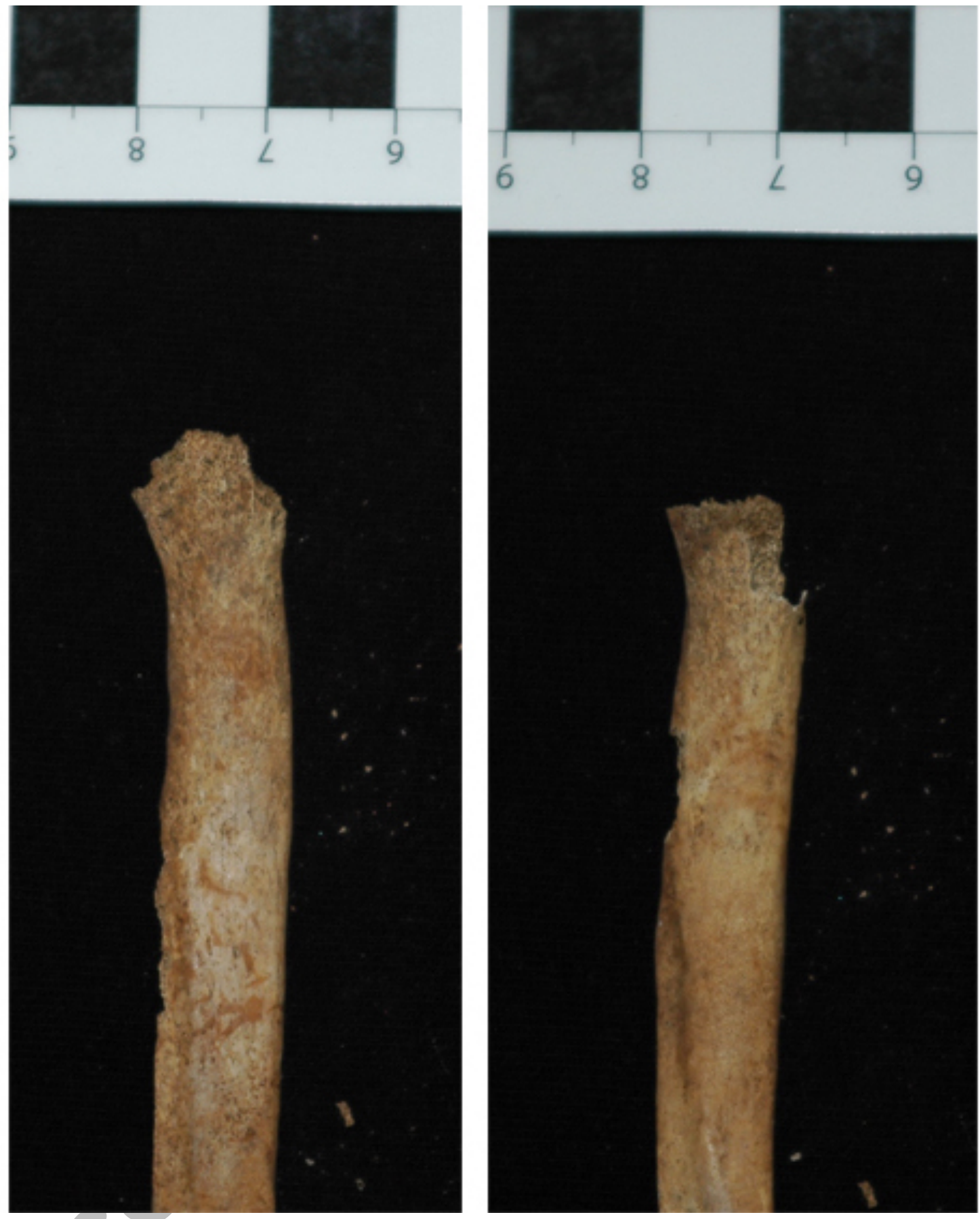

Figure 9. Enlarged sternal rib ends. From Butt Road, Colchester, skeleton 145 (with permission from Colchester and Ipswich Museums). 


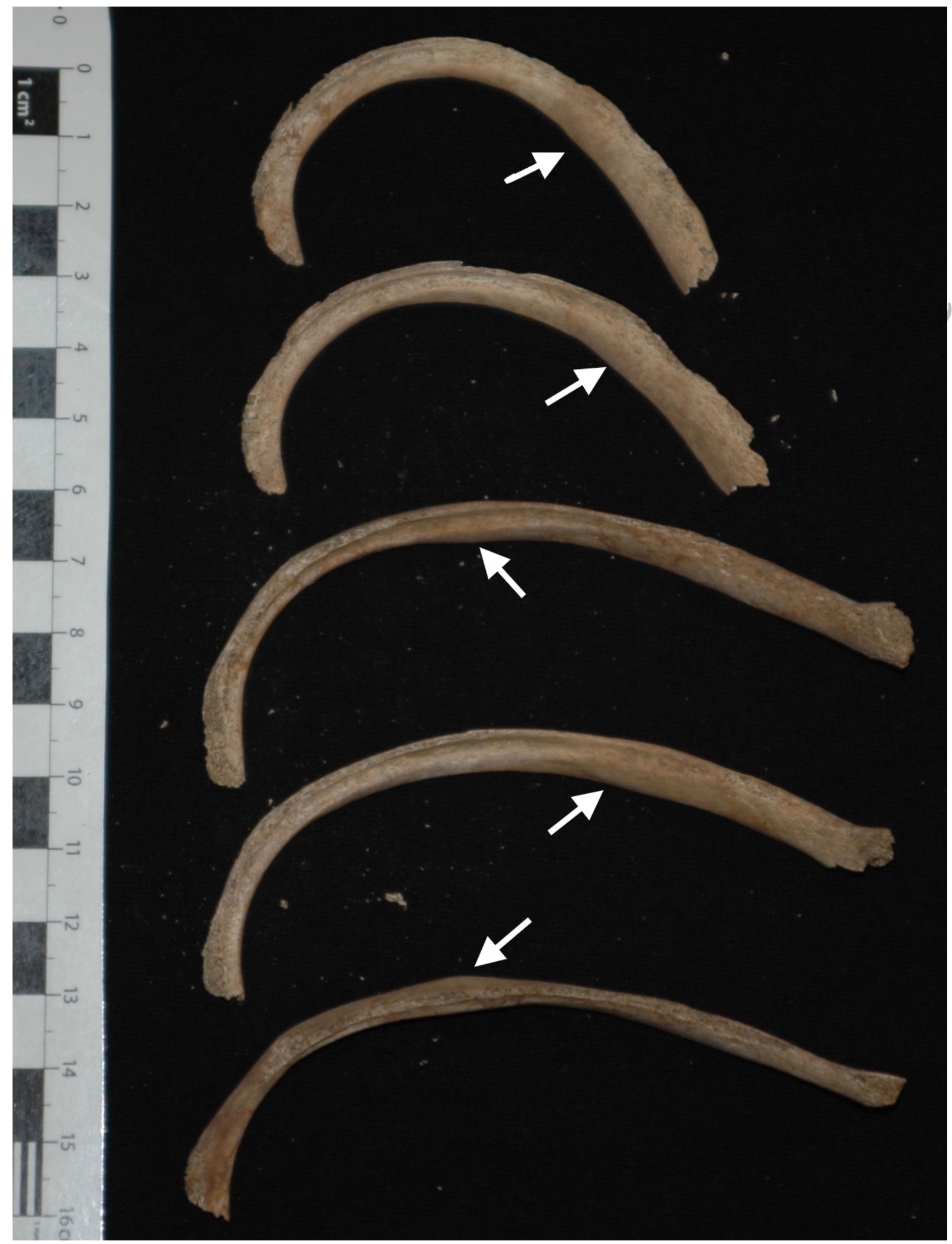

Figure 10. Right ribs, inferior. Localised masses on rib shafts (arrows); dense cortical foci rather than new bone deposits. Locations not uniform. From Butt Road, Colchester, skeleton 145 (with permission from Colchester and Ipswich Museums). 

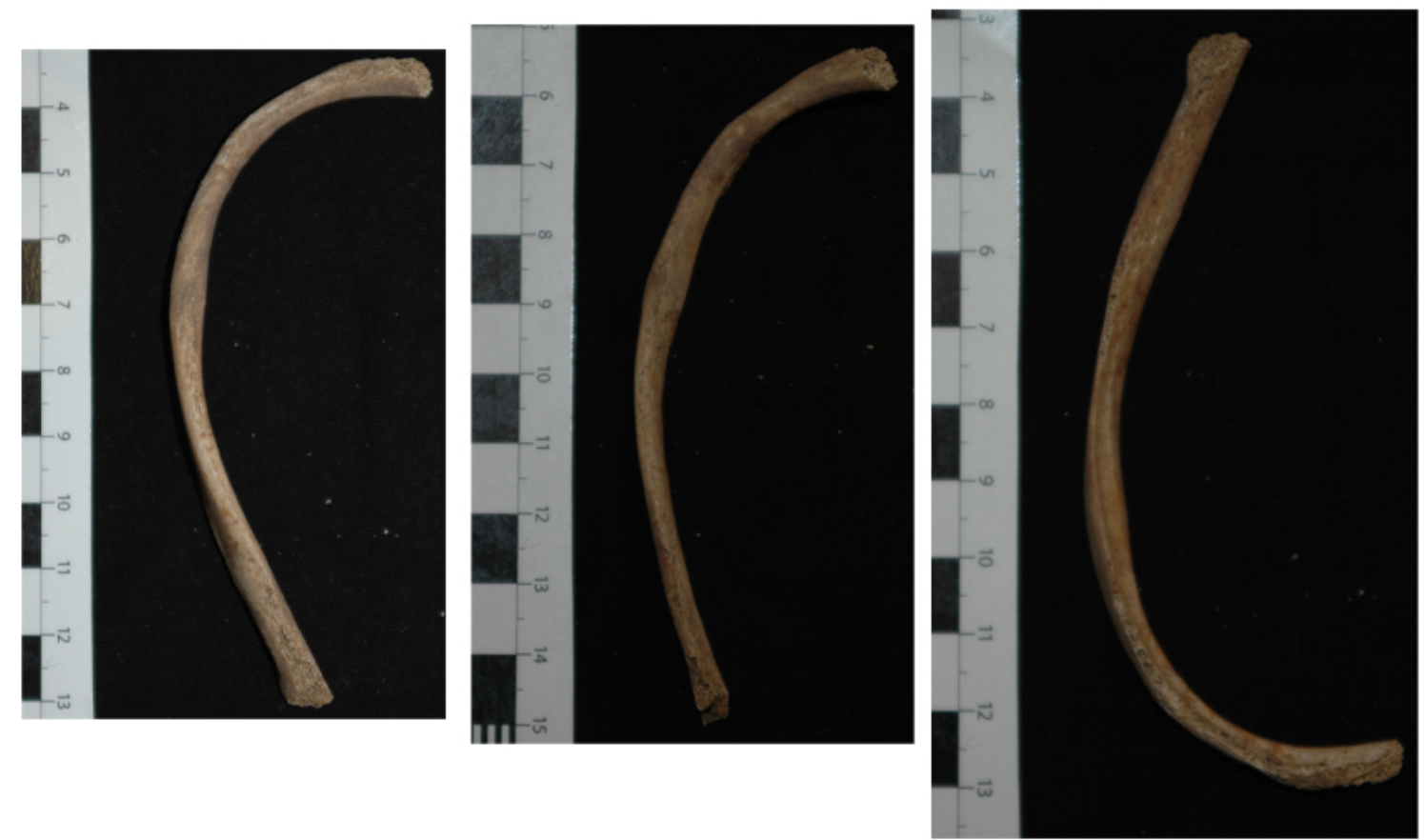

Figure 11. Right ribs, superior and inferior (far right) allowing a better view of the expanded foci on rib shafts. Masses blend into the existing shape of the bone. From Butt Road, Colchester, skeleton 145 (with permission from Colchester and Ipswich Museums). 

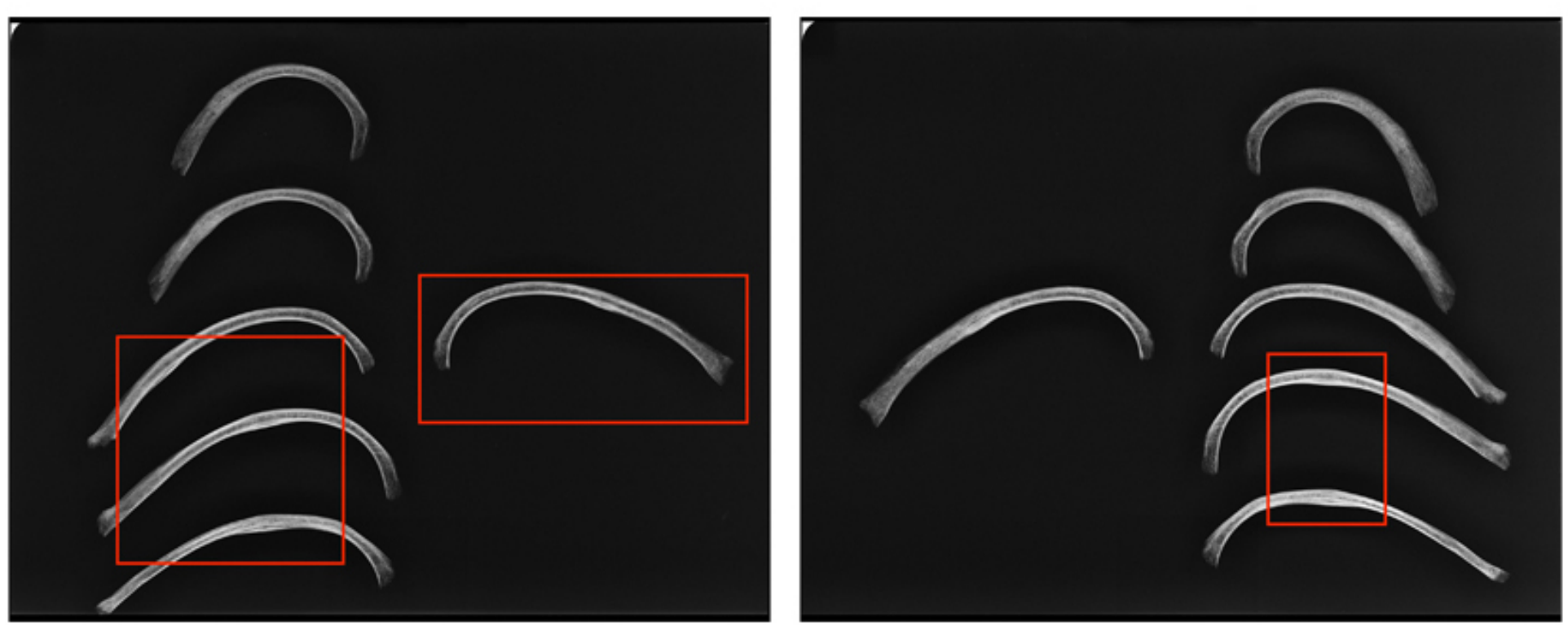

Figure 12. Digital radiographs of ribs superiorly (left) and inferiorly (right) with localised masses. Radio-opaque appearance of localised masses. Costal osteomas deposited on the original cortex, rather than expansion of the rib shaft. From Butt Road, Colchester, skeleton 145 (with permission from Colchester and Ipswich Museums). 

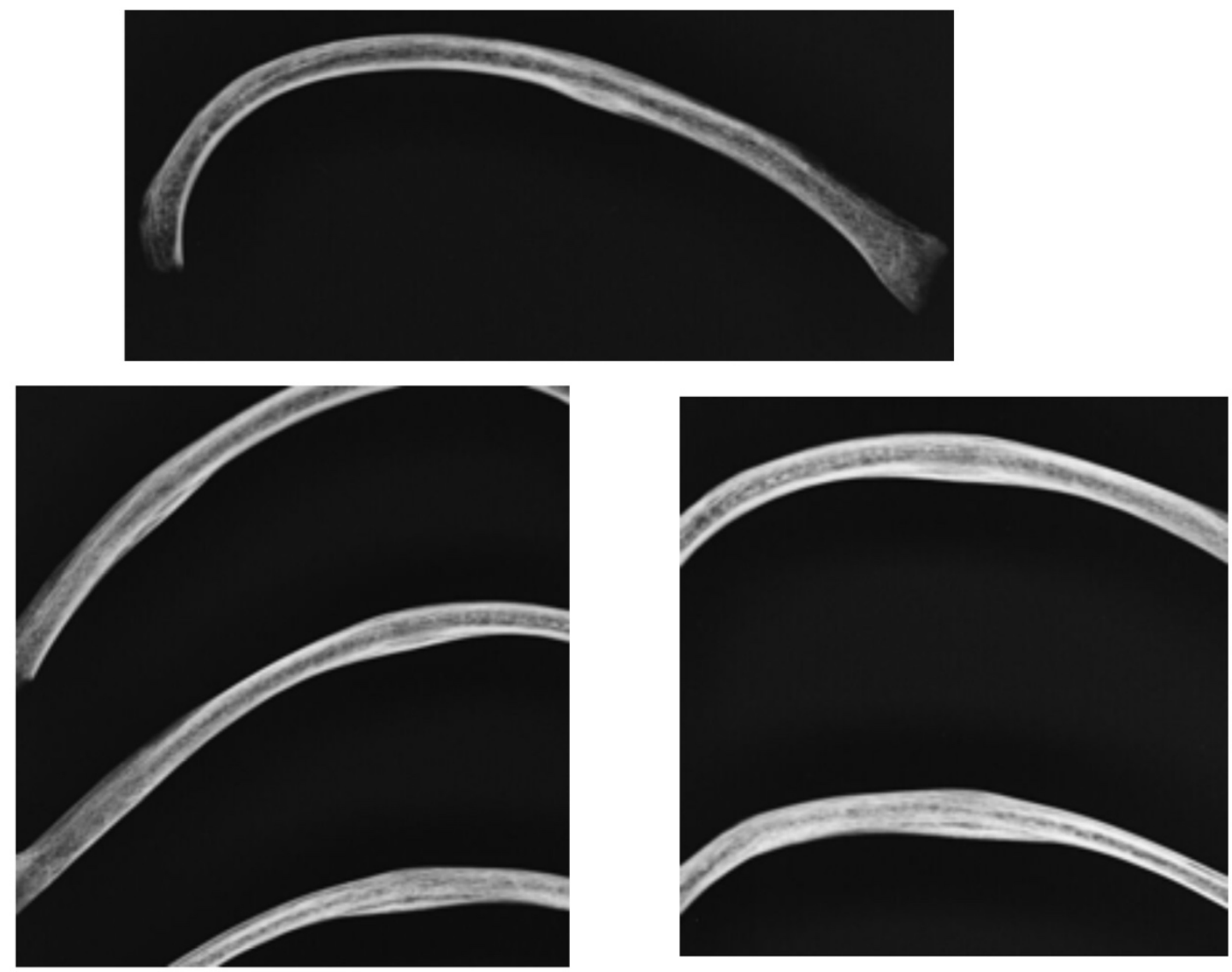

Figure 13. Enlarged radiographs of localised masses on ribs. Left rib superior (top), right ribs superior (bottom left), right ribs inferior (bottom right). Radio-opaque appearance of the localised masses on top of the original cortex, rather than blending of original and new bone, no fracture lines apparent. From Butt Road, Colchester, skeleton 145 (with permission from Colchester and Ipswich Museums). 